\title{
Effectiveness of Teachers' use of Motivational Skills to enhance Student's Academic Learning outcome
}

\author{
Kuenzang Tobgay
}

\author{
Teacher, Tsebar Lower Secondary School, Pemagatshel: District Bhutan. \\ Received: 09 Jul 2021; Received in revised form: 15 Aug 2021; Accepted: 21 Aug 2021 \\ (C)2021 The Author(s). Published by TheShillonga. This is an open access article under the CC BY license \\ (https://creativecommons.org/licenses/by/4.0/)
}

\begin{abstract}
In this study, the researcher has a purpose to inform all our teachers, students, and parents about the impact on the effective use of teachers' motivational skills in the teaching-learning process. The purpose and importance of motivation should be clearly understood by the teachers. The fundamental aim of effective use of teacher's motivational skills is to stimulate and facilitate any learning activity. So teachers have a lot to do with student's motivational learning as an effective form of learning is not possible without motivation.

A student may attend the class with a certain degree of motivation, but the teacher's behavior, teaching styles, the nature of the classroom environment, and informal interaction with students all have a large effect on student motivation. Since motivation help students to concentrate better and gain satisfaction, teachers need to provide continuous motivation in every teaching lesson.

This paper was a qualitative study based on in-depth semi-structured interviews which were limited to eighteen key informants due to the small size of the community. Data were analyzed with a content analysis approach. The study was conducted in two different schools in the same district.
\end{abstract}

The study determined that most of all our teachers in their various workplaces are experiencing numerous challenges and hardships while working hard to make teaching-learning interesting and meaningful. Some of the impeding factors included: lack of resources and training, lack of parental support and guidance, behavior and feedback, and the teacher-student relationship.

The findings revealed that to encourage learners to learn more effectively and become lifelong learners, our teachers need to enhance their knowledge and skills through the provision of various training, workshops, seminars, and other exchange programs on regular basis. If only then teachers motivate students, they will ultimately realize the learning purpose and achievable goal.

Keywords-Bhutan, Motivational skills, Teaching Strategies.

\section{INTRODUCTION}

Bhutan is a small Himalayan landlocked country with a unique and spectacular culture and tradition, rich religious festivals, significant historic monuments, and a pristine environment, and it is situated in South Asia, bordering China in the North and India in the south with an area of

38,394 square kilometers. With the start of modernization in the late 1950s, a modern education system was introduced in the country which opened a new chapter in the history of Education in Bhutan. The progress in the educational arena had been tremendous and far-reaching, so much so that it has brought extraordinary changes in the social, cultural, political, and economic structures (Phuntsho, 2000, p.97).

One of the greatest challenges for the education sector in Bhutan is to maintain the quality of education. There has been a general perception that the quality of education has deteriorated and Bhutan has to improve the standard of education (Royal Education Council, 2008). There is a lot of debate taking place amongst educators, professionals, and parents in the media and still, it is a bone of argument in today's Bhutanese society that the quality of education is deteriorating (Royal Education Council, 2009). One of the 
crucial ways to improve the quality of education is absolutely through improving the teachers' competence and their motivational skills so that it will help to enhance student's academic learning outcomes.

The Ministry of Education over the past years has initiated numerous changes and some vital reforms across schools in Bhutan. One of the major shifts in the education system of the $21^{\text {st }}$ century is the focus on the child-centered learning approach from the traditional teacher-directed approach across all schools irrespective of the levels. This paradigm shift aims to ensure that student's learning takes place effectively through the teacher's ability to use multiple motivational skills and other teaching strategies to reach the intended learning goals of both the learners and the teachers.

Motivation is considered to be one of the key elements that have a considerable impact on students' learning and it is regarded as highly essential in all aspects of promoting effective learning. The success of student's learning depends on the teachers' use of motivational skills, therefore, good and effective use of the motivation skills by the teachers is essential to success in the teachinglearning process.

This research study begins with the concept definition of motivation and describes the types of motivation and theories on motivation. Finally, it addresses how teachers as sources and agents of change can help to motivate students to achieve the desired learning outcome.

\section{LITERATURE REVIEW}

\subsection{Concept Definition of Motivation.}

Myers (1996, p. 297) stated that "motivation is a need or desire that serves to energize behavior and to direct it towards a goal." According to this definition, motivation is a source to move the person to the task. According to Smith (1988, p. 27) motivation is defined as

"psychological forces that determine the direction of a person's behavior, a person's level of effort, and a person's level of persistence in the face of obstacles." Motivation inspires a person in doing everything to achieve the desired goal (Brown, 2001 p.75). Whenever teachers motivate their students it becomes much easier for them to achieve their task and without it, this is difficult to achieve.

\subsection{Types of Motivation.}

Teacher's use of motivational skills is an important factor in encouraging student's participation in classroom activities (Stipek, 1996, p.96). According to Dornyei (2003, p.5) motivation is categorized into intrinsic and extrinsic motivations that affect the achievement of students.

\subsubsection{Intrinsic Motivation}

Intrinsic motivation is the desire to do something for pleasure and satisfaction as a part of either enjoyment or obligation (Maslow, 1943, p. 13). On the other hand, Dornyei (2001) claims that intrinsic motivation is selfdetermined and refers to internal factors such as enjoyment and satisfaction for oneself. Further, Zhang and Bartol (2010) argued that intrinsic motivation is the inner drive of a person to carry out the task, and works for the sake of the task itself. When a person is intrinsically motivated he or she will perform the behavior voluntarily, in the absence of material rewards or external constraints (Deci\& Ryan, 1985). Intrinsic motivation also arises from a desire to learn a topic due to its inherent interests, for selffulfillment, enjoyment, and to achieve a mastery of the subject in one's life (Maslow, 1943, p.15). According to Burden (2000, p.147), "Intrinsic motivation is a response to needs that exists within the student, such as curiosity, the need to know, and feelings of competence or growth. Furthermore, Ryan and Deci (2000, p.13) stated, "the feelings of satisfaction in intrinsic motivation come from a sense of competence, autonomy, and relatedness." Marsh (1996, p.35) states "Intrinsic motivation is more influential to learners than extrinsic motivation because intrinsic motivation heightens learner from self and within remaining uninfluenced by the external factors. This makes a learner aware that they need to learn anything with interest and enjoyment.

\subsubsection{Extrinsic motivation}

According to Brown (2007, p. 213), "Extrinsic motivation refers to motivation that comes from outside an individual. The motivating factors are external, or outside, rewards such as money or grades. These rewards provide satisfaction and pleasure that the task itself may not provide." Sansone and Harackiewicz (2000, p.111) rightly mentioned that:

Learners who are extrinsically motivated will work on a task even when they have little interest in it because of the anticipated satisfaction they will get from some reward. The rewards can be something as minor as a smiley face to something major like fame or fortune. For example, an extrinsically motivated child in a class who dislikes learning math subjects may work hard on a math equation because he or she wants the reward for completing it. In this case, a student can be rewarded with a good grade on an assignment or shouting cheers for him. 
Extrinsic motivation is a motivation from outside for the learner and has to do with external rewards. Words of praise from the teacher, a privilege, and a higher grade in a paper are some examples. Rewarding students for participating in an exciting activity is not necessary, but extrinsic rewards may be needed after an activity that students find less intrinsically interesting and satisfying (Burden, 2000). Hence, using encouraging words by the teacher seems vital in increasing student's participatory level in learning.

According to Noels and Clement (2001,p.116), extrinsic motivation does not mean, however, that a person will not get any pleasure from working on or completing a task. It just means that the pleasure they anticipate from some external reward will continue to be a motivator even when the task to be done holds little or no interest. Extrinsic motivation refers to the motivation one has to participate in an activity, not for the joy of it, but to accomplish some external goal (Ryan \&Deci, 1985; Dornyei, 1998). For instance, an individual who participates in an activity to receive praise, money, or a reward, as well as avoiding punishment from an external figure is characterized as possessing extrinsic motivation.

\subsection{Theories on motivation}

There are many motivational theories in literature theorized by different writers and researchers, but found that no particular theory is perfect of its own. It is dependent on one another and does not apply to all situations independently. However, by looking at the key ideas behind each theory, we can gain a better understanding of motivation as a whole. The theories that are found significantly appropriate to this research study are 1. Instinct theory. 2. Incentive theory. 3. Cognitive dissonance theory of motivation. 4. Abraham Maslow's hierarchy of needs theory which under each of these are introduced separately.

\subsubsection{Instinct Theory of Motivation}

Instinct theory proposes that "organisms engage in certain behaviors because they lead to success in terms of natural selection. Instinct theory casts motivation as essentially intrinsic and biologically based. According to the instinct theory, people are motivated to behave in certain ways because they are evolutionarily programmed to do so. An example of this in the animal world is seasonal migration. These animals do not learn to do this; it is instead an inborn pattern of behavior.

\subsubsection{Incentive Theory of Motivation}

According to this theory, "people are pulled toward behaviors that offer positive incentives and pushed away from behaviors associated with negative incentives. In other words, differences in behavior from one person to another or from one situation to another can be traced to the incentives available and the value a person places on those incentives at the time" (Bernstein, 2011, p.164). The incentive theory suggests that people are motivated to do things because of external rewards. For example, one might be motivated to go to work each day for monetary rewards or for being paid.

\subsubsection{Cognitive dissonance theory of Motivation}

Self- determination theory, developed by Edward Deci and Richard Ryan (1985) focuses on the importance of intrinsic motivation in driving human behavior. This occurs when an individual experiences some degree of discomfort resulting from an incompatibility between two cognitions. For example, a consumer may seek to reassure himself or herself regarding a purchase or may have a feeling, in retrospect, that another decision may have been preferable.

\subsubsection{Abraham Maslow's Hierarchy of Needs Theory}

Some writers say that motivation is associated with the needs in the day to day life and to perform better. Maslow's (1943) need-based theory of motivation suggests that a person has five fundamental needs: physiological, security, affiliation, esteem, and self-actualization. The physiological needs include pay, food, shelter and clothing, and comfortable work conditions. The security needs include the need for safety, fair treatment, protection against threats, and job security. Affiliation needs include the needs of being loved, accepted, and being a part of the group, whereas esteem needs include the need for recognition, respect, achievement, autonomy, and independence.

Finally, self-actualization needs, which are the highest in the level of Maslow's need theory, include realizing one's full potential or self-development; the author calls it the pinnacle of one's calling. According to Maslow, once a need is satisfied it is no longer a need. It ceases to motivate employees' behavior and they are motivated by the need at the next level up the hierarchy. So motivation is directly linked to the needs of an individual and as individual needs are fulfilled the level of motivation decreases or diminishes over some time.

\subsection{Teachers' role as facilitators in motivating students}

Brown, Armstrong, and Thompson (1998, p.105) state, "Well motivated students have always succeeded in higher education and will continue to do, so the challenge has always been to stimulate, engender and enhance the motivation of those students whose enthusiasm for learning cannot be taken for granted." Teaching students is 
not exactly easy, and motivating students to learn and become more inquisitive is even more difficult. Motivation is closely associated with every teacher's potentials and skills to make it positively happen with children in the class to excitingly get engrossed in daily learning experiences.

The kind of motivation that comes from teachers plays a significant role in students' learning. Stipek, (2000, p. 107) emphasized that "Teachers are instrumental in creating the kind of learning atmosphere in the classroom, as teachers are in control of most aspects of instructions as well as the social climate in the classroom." Teachers who take time to develop positive relationships with their students will see improvement in their students both academically, behaviorally, and emotionally.

As this is a general goal of academic culture, it makes sense that more effort is needed to foster a similar sense of connectedness in the classroom context specifically (Ryan \&Deci 2000). Stipek,

(2002, p.14) mentioned, "I have seen teachers' dramatically affect the motivation of even the most recalcitrant students." Hence, it is imperative to study the fact as to what extent teachers can fulfill learning needs and help students become a self-directed and lifelong learner.

Teachers can maintain motivation to make the learning experience enjoyable and stimulating. This can occur in various ways. For instance, teachers can make teaching more interesting by varying their teaching styles, presentations, different materials, and learning task. Interesting tasks have been viewed as one of the greatest components of motivation (Anderman \& Anderman, 2010).

To enhance a greater level of students' motivation, teachers can establish interesting classes by creating learning materials that are relevant to the students' interests. According to Smith $(1978$, p.176) if a teacher reaches out to students and shows them how concerned and interested he or she is and develops a good rapport, then the students are motivated to learn and accomplish greater academic learning outcomes. Teven and Mc Croskey (1997) pointed out that students who believe their teacher is caring, motivating, and encouraging can help in achieving greater academic outcomes. Further, positive relationships with teachers predict enhanced social, cognitive, and language development in younger children (Kontos\& WilcoxHerzog, 1997).

In the words of Chauhan (2003, p. 16) teachers need to provide a proper learning environment both inside and outside of the classroom to motivate students. Therefore, teacher's attitude and enthusiasm is a very important factor that will create a better environment for student's motivation in their learning. Bowd, Mc Dougall\&Yewchuk (1998, p.147) emphasized teachers' role models and behavior as one of the factors that greatly affect the student's motivation.

\section{METHODOLOGY}

\subsection{Research Location}

The study area is located in the Eastern part of the country of Pema Gatshel District. The research was conducted at two community primary schools with classes from preprimary through grade six. primary school classes have one section each consisting of 20 to 25 students. Zobel and Dungmin primary schools were preferred for the study, as they were located at an approximate traveling distance of not less than fifty minutes away from my present school and that had some basic amenities such as electricity, telephone computers so, as to have sufficient and comfortable times to conduct my study.

\subsection{Research Design.}

This research was qualitative in orientation and was based on in-depth interviews with semi-structured questions used to obtain the utmost appropriate and insightful information required. In-depth interviewing is a qualitative research method encompassed in conducting and understanding with a small number of key participants to examine their opinions on a specific idea, program, or situation. The indepth interview was the preferred approach to acquire the needed data in this research because the key informants would be more likely to get included rather than if they were sent interview questions to read on their own. As Miles \& Gilbert (2005) pointed out, semi structured interviews are discussions grounded on the investigator's questions designed at encouraging a discussion where the interviewee feels comfortable and says what he or she thinks about the topic. This research had several limitations, with small sizes of the study area and small size of the sample, and very limited time and budget constraints.

\section{DATA COLLECTION AND ANALYSIS}

Data were collected from 18 key informants consisting of six teachers and twelve students from two different schools for two weeks. A total of six teacher key informants participated in this study, two females and four males. A total of twelve student key informants participated, six males and six females. This is because the schools being located in remote places of the district. The researcher has employed a purposeful sampling approach to enable an indepth investigation of the study. To ensure every key informant's response was free, lively, and confident, the 
interview guidelines were translated into the national language of Bhutan, and responses were later translated and transcribed for the data analysis. Notes were taken during the time of the interview to check for reliability, and the data was also supported by the recordings in the recording machine.

Creswell (2007, p.148) states, "data analysis in qualitative research consists of preparing and organizing the data for analysis, then into themes through a process of coding and condensing the codes, and finally representing the data in figures, tables, or a discussion". In this study, the content analysis technique was employed to analyze and determine the findings of this research.

\section{FINDINGS}

This study aimed to explore how teaching strategies that teachers employ in regular classroom teaching raise students' level of motivation to learn effectively. The findings on how teacher-related factors, child-related factors, and challenges teachers face determining students' learning are discussed below.

\subsection{Teacher Related Factor.}

\subsubsection{Types of teaching strategies used by teachers}

The study reveals that teachers in the school do not employ various teaching strategies in the teaching-learning process. Among many teaching strategies, teacher key informants believe and prefer using the lecture method followed by a demonstration, chalk, and board and question-answer method. Teacher participants reported that they favor the lecture method, as it is flexible and applicable to all content areas irrespective of grades and subjects. The concern of syllabus coverage on time had made the teachers choose these strategies which students simply listen to teaching passively. Similarly, the majority of the student key informants also revealed that their teachers use the lecture method in classroom teaching.

The study found out that the least employed teaching strategies by teachers were demonstration methods, group activities, role play, and cooperative learning approach. Both teacher and student key informants explained that teachers hardly employ various teaching strategies because of time constraints and the need to hurry up for coverage of vast prescribed syllabus for each subject. However, it was revealed that the majority of teacher participants admitted that, the motivational level of learners is stimulated and learning is influenced by the teacher's use of various strategies.

\subsubsection{Teaching styles and learning impact}

As Darling-Hammond (2006, p.4) explains it, "teaching is in the service of students, which creates the expectation that teachers will be able to come to understand how students learn and what students need if they are to learn effectively - and that they will incorporate that into their teaching". It was found out that from observation of classroom teaching, teachers' key informants hardly use any interactive and participatory learning approach during the teaching and learning sessions in classrooms. The student key informants mentioned that the teachers often use the same teaching strategies for teaching which create learning uninterested, unmotivated, inattentive, sleepy, and bored. Further, it was found out that the teaching strategies the teachers apply in the teaching and learning process have an immense impact on student's motivation to learn effectively.

\subsubsection{Teacher's best choice of teaching strategies}

The majority of teacher key participants expressed that they preferred the direct lecture method over numerous other methods and strategies. Centre for Education Research Division (2009), noted that the Bhutanese education system has many teachers in the system that go for a very rigid, chalk and talk kind of method similar to the one noticed by UNESCO (2004) in sub- Saharan Africa. The teacher key participants mentioned that the lecture method is straight forward way to impart knowledge to the students and consider this approach help the teachers save time and overcome the challenges of large classroom size, and fulfill the diverse needs of the various subjects. Dornyei, (2007, p.730) asserted that, as long as we are aware of the vast repertoire of techniques that are at our disposal, it is up to us to choose the specific ones that we will apply, based on the specific needs that arise in our concrete circumstances. Hence, teachers must choose varied forms of strategy that enhances student's interest and fulfill learning needs. Teachers' behavior and feedback

The study revealed that teacher's behavior, beliefs, actions, and conduct greatly affect student engagement in their daily classroom learning. A teacher's commitment to his or her work, learning styles, and work ethics truly inspires students to learn. Bowd et al. (1982, p.147) expressed that the opinion that teachers as role models affect the motivation level of their students and children are also likely to intimate their teacher's behavior.

All teacher participants pointed out that providing timely constructive feedback and carrying out mandatory followup enhances the students motivating factor in the learning process. The teacher key informants explained that the timely provision of positive and constructive feedback by 
teachers helps students become more interested and encouraged to learn, which results in students working with high motivation levels.

\subsubsection{Teacher-student relationship}

The key participants stated that the teacher-student relationship could play in influencing children's participation in ensuring successful teaching and learning. The study revealed that a very close and friendly relationship with children develops good faith and trust and the learners become internally motivated and remain attentive to the teacher's teaching. The study also suggested that the web of relationships in the classroom among students and the teacher creates an optimal learning environment. Center for Education Research Division (2009) noted that Bhutanese teachers generally possess a caring nature for the students and demonstrate a high level of friendliness and openness.

\subsection{Child Related factors}

5.2.1. Children's perspective of the best teaching strategies

The student key informants suggested that the learning becomes easier and better when the teachers employ various teaching strategies during the teaching and learning process. They expressed that the learning becomes more interesting and meaningful when the teachers incorporated various teaching skills and strategies. Both teacher and student key informants expressed that some notable changes with the general classroom setting to teachers' use of multiple strategies have occurred as a result of the introduction of transformative pedagogy in teaching. However, all teacher participants admitted some prominent challenges they faced while implementing the desired form of teaching strategies such as crowded classrooms, the vastness of the prescribed syllabus, limited time and resource constraints.

\subsubsection{Lack of proper parental support and guidance}

The key participants expressed the need for proper parental support and guidance to improve children's learning. They expressed that parental influence at home affects learning in the classroom. Haynes, Comer, and Hamilton- Lee (1989) pointed out that positive parental support and care are associated with better attendance, greater willingness to do homework, and higher academic achievement. The study revealed that most of the students come from farming backgrounds, where parents work in the fields. Parents of such families keep themselves busy with their farm works and do not get adequate time to provide guidance, monitoring, and encouragement to their children's schoolwork. The student key informants expressed that they aspect the parents and the school should develop a positive relationship to enhance their academic achievement. Close coordination and positive relationships between home and the school also increase a sense of continuity in the lives of young children, an important foundation for success as children grow and make transitions (Berger, 2000).

\section{CONCLUSION AND RECOMMENDATION}

This study mainly discussed if teaching strategies that teachers employed raise students' level of motivation to learn effectively. It focused on the relationship between teaching strategies and motivation. The study addressed some major influential theories of motivation, factors affecting learner's motivation, and the role of the teacher in enhancing learner's motivation and helping them achieve continuous progress in the learning process.

In improving students' motivation, we need to pay attention to some prevailing factors. First, we must set goals that are meaningful, realistic, and achievable for students. All teaching requires setting goals, establishing objectives, selecting and implementing strategies and techniques to achieve those learning objectives, and evaluating the entire teaching process in terms of its effectiveness. Teachers need to take up the challenge and use as many different instructional approaches as possible to help students learn. Teachers must set a conducive and interesting learning environment. Students want a teacher to maintain an orderly and structured classroom environment, to explain matters clearly, to be fair and consistent, and to be aware of the needs of the class. Students who feel good about themselves are more likely to be motivated to learn.

Strengthening good relationships with both students and parents can make learning visible and even more meaningful. In the process of building up good relationships, it is important to involve students in some decision-making processes such as, formulation of classroom rules and identifying some consequences for inappropriate behavior as much as possible. In addition, it is so significant that teachers should be aware of their actions and behavior in the classroom because it is very likely that teacher's actions and behavior can either enhance student's motivation or can also demotivate learners.

Several recommendations can be considered for future research:

1. An interesting and authenticated results would be obtained if such research is carried out widely with 
teachers and students of even the private schools across the country.

2. A similar kind of study could also be conducted in higher and middle secondary schools involving teachers and students for better results and analysis.

3. The participants for the study could also include school administrators and parents as they were excluded in this particular study.

\section{REFERENCES}

[1] Anderman, E.M., \& Anderman, L. H. (2010). Classroom motivation. Upper Saddle River, NJ: Merrill. Approaches (2nd ed.). New Delhi: Saga Publication.

[2] Berger, E.H. (2000). Parents as partners in education (5th ed.). Columbus, $\mathrm{OH}$ : Merrill- Prentice- Hall.

[3] Bernstein, D.A. (2011). Essentials of Psychology (5 $5^{\text {th }}$ ed.). Belmont, C.A. Wadsworth Cengage Learning.

[4] Bowd, A., Mc Dougall, D., and Yewcuk, C. (1998). Educational Psychology for Canadian teachers (2 ed.). Harcourt Brace \& Co. Toronto.

[5] Brown, G. \& Atkins, M. (1988). Effective teaching in higher education. London: Routledge.

[6] Brown, S., Armstrong, S., Thomson, G. (1998) Motivating students: The impact of teaching: California: Corwin Press, Inc.

[7] Burden, P. R. (2000). Powerful classroom management strategies; Motivating students to learn. New York: Brown Company Publishers.

[8] CERD (2009). Quality of education in Bhutan. RUB: Paro.

[9] Chauhan, S. S. (2003). Advanced Educational Psychology (6th ed.). New Delhi: VikasPublishing House Pvt. Ltd. (2nd ed.). Florida State University: New Jersey.

[10] Creswell, J. W. (2007). Qualitative inquiry and research design: Choosing among five approaches (2nd ed.). New Delhi: Sage Publication.

[11] Darling Hammond, L., Strobel, K., \& Martin. (2003). The expectation for success: motivation and learning. Stanford University: Mort Crems Communications.

[12] Deci, E. L. \& Ryan, R. M. (1985). Intrinsic motivation and self-determination in human motivation and selfdetermination in human behavior. New York: Plenum.

[13] Dornyei, Z, (2003). Motivational strategies in the language classroom.UK: Cambridge University Press.

[14] Dornyei, Z., \&Ushioda, E. (2011). Teaching and researching motivation (2nd ed.). Harlow, England: Pearson Longman.

[15] Haynes, N.M., Comer, J.P., \& Hamilton- Lee, M. (1989). School climate enhancement through parent involvement. Journal of school psychology, 27, 87-90.

[16] Kontos, S., \& Wilcox-Herzog, A. (1997). Influences on children's competence in early childhood Classrooms. Early Childhood Research Quarterly, 12, 247-262.

[17] Maslow, A.H. (1943). Motivation and personality. New York: Hoyer Brown Co.
[18] Marsh, Colin. (1996). Handbook for beginning teachers. South Melbourne: Australia. Longman.

[19] Miles, J. \& Gilbert, P. (2005). A handbook of research methods for clinical and health psychology(pp.12): Oxford University Press on Demand.

[20] Myers, M. R. (1996). Addressing parents' concern over curricular reforms. Educational leadership. (53) 7, 54-57.

[21] Noels, K.A., Clement, R., \& Pelletier, L.G. (2001). Intrinsic, extrinsic, and integrative orientations on students' motivation; Interactivity and Extrinsic motivation force in learning. London: Oxford Press.

[22] Phuntsho, K. (2000). The two ways of learning in Bhutan. Journal of Bhutan studies. 2(2), 96-101.

[23] Royal Education Council. (2008). Teacher quality enhancement project, policy guidelines \& strategic plan.Thimphu, Bhutan: REC.

[24] Royal Education Council. (2009). The quality of school education in Bhutan: reality \& opportunities. Thimphu: REC.

[25] Ryan, R.M. \&Deci, E.L. (2000). Intrinsic and extrinsic motivations: Classic definitions and new directions. Contemporary Educational Psychology, 25, 12-28.

[26] Sansone, C. \&Harackiewicz, J. (2000). Intrinsic and Extrinsic Motivation. Academic Press.

[27] Smith, F. (1978). Understanding learners' motivation in the classroom setting. New York: Holt, Rinehart \& Winston, Inc.

[28] Stipek, D. (2002). Motivation to learn. New York: Macmillan. Academic Press.

[29] Stipek, D. J. (1996). Motivation and instruction. In D. C. Berliner \& R. C. Calfee (Eds.), Handbook of educational psychology (pp. 85-113). New York: Macmillan.

[30] Teven, J., \&McCroskey, J. (1997). The relationship of perceived teacher caring with student learning and teacher evaluation. Communication Education, 46, 1-9.

[31] Zhang, X., \&Bartol, K. M. (2010). Linking empowering leadership and employee creativity: The influence of psychological empowerment, intrinsic motivation, and creative process engagement. Academy of Management Journal, 53(1), 107-128. 